\title{
MALT, MILTON, AND MSS.
}

\section{BY ROBER'T MAR'TIN ADAMS}

THE writer of this lively description of the Library's fine lot of first editions and manuscripts of modern authors, an Assistant Professor of English at Rutgers, has published critical articles on various contemporary literary figures in CROSS SECTION 1948, the NEW ENGLAND QUARTERLY, ACCENT, CRONOS, and SEWANEE REVIEW.

\section{... And malt does more than Milton can}

To justify God's ways to man....

$\mathrm{I}$

T'S an old tradition that inns attract authors. Chaucer wet his whistle at the Tabard, Shakespeare at the Mermaid Tavern, Dr. 1 Johnson at the Mitre, and Hemingway's generation at the Café Rotonde. Writers who are contemporary, successful, and in New York are apt to be found bending elbows at the 21 Club, on West 52 nd Street. A partner in The House of $2 \mathrm{I}$ is I. Robert Kriendler (Rutgers, '36), who absorbed a love of letters during his stay along the Raritan. Hence, by a natural transition, arose the I. Robert Kriendler Collection of Typescripts, Manuscripts, and Autographed Volumes of Contemporary Authors, now lodged in a large, glass-covered, earlymid-Victorian credenza, near the postern-gate in the remote southeast crypt of the Library's left wing.

Staunchest of Host Kriendler's customers, and most splendid of the contributors to the Collection, is John O'Hara. Sixty-six typescripts of O'Hara stories and sketches printed by the New Yorker attest his generosity. All contain author's corrections and printer's marks, and provide real insight into the making of America's hardest contemporary prose. The author of Butterfield 8 and Pal Joey has also autographed a copy of his omnibus Here's O'Hara for the Library, adding to his signature a couple of lines from "On the Banks":

\section{... and there she stood}

Since the time of the Flood.

The rhyme, or lack of it, has been fascinating him, he says, for years.

As a class, the historians of saloon society are naturally well represented in the Collection. Autographed volumes and typescripts bearing such names as Louis Sobol, Ward Morehouse, Jack Miley, 
Nick Kenny, Lucius Beebe, and Drew Pearson form a good part of the material. But sportsmen, politicians, businessmen, and even royalty are also represented. The Babe Ruth Story is autographed by the Bambino and by his literary helper Bob Considine. There are books inscribed by Rex Stout, Jim Farley, Donald M. Nelson, Elliott Roosevelt, Bartley Crum, Colonel Carlos Romulo, Louella (The Gay Illiterate) Parsons, and Her Highness the Ranee of Sarawak. Ely Culbertson, in a moment of enthusiasm, inscribes his autobiography "To Rutgers, which is greater than Yale"; and Kathleen Winsor writes a bold, broad hand across the endpapers of Forever Amber.

Some of the donors have been inspired by the occasion to comments either fanciful or somber. In a festive academic mood, Oscar Levant inscribed a copy of his Smattering of Ignorance with the learned motto, "Hic haec hoc (and I mean it)." George Jessel, presenting his autobiography So Help $M e$ to the Rutgers Library, added "AND I'M PROUD TO BE IN IT." More soberly, Morris Ernst in a copy of The First Freedom hailed the Rutgers Library as "A citadel of Freedom." And Ludwig Bemelmans, who is equally talented as boniface, as world-traveller, as author, and as artist, scrawled a mock-pretentious self-portrait over his autograph.

Literary stars of all magnitudes burn in the heavens of $2 \mathrm{I}$. H. L. Mencken, forsaking the beer-steubens of Baltimore, inscribes a copy of his Happy Days for Host Kriendler and Rutgers. Rebecca West contributes a signed copy of her monumental study of Yugoslavia, Black Lamb and Grey Falcon. John Steinbeck is represented by The Red Pony and The Wayward Bus. A copy of Mister Roberts is inscribed by both Thomas Heggen, who wrote the novel, and Joshua Logan, who dramatized and produced it. John Hersey autographs Hiroshima and John Gunther Inside USA. A youthful contact with Rutgers is renewed by Stephen Longstreet, author of the musical High Button Shoes and old-time resident of New Brunswick, who inscribes a copy of his Decade 1929-1939 to the Rutgers Library, "where I read many books."

Particularly interesting features of the Collection are typescripts and manuscripts by such authors as Somerset Maugham, Stephen Vincent Benet, Edna Ferber, Zona Gale, and Alexander Woollcott. Robert Nathan donates one especially intriguing script. His short 
story, "Mr. Whittle and the Morning Star," is shown in all its various stages, from the original manuscript false starts, through the first pencilled draft, to the author's final typescript and last corrections. Even Hollywood's golden fleshpots have contributed to the Collection. From the late Mark Hellinger's studio come four bloodthirsty scripts-Swell Guy, The Killers, Brute Force, and Homicide. Such material, hot from the writer's workshop, will be of the greatest interest to budding authors.

The world of American letters, as it passes through the $2 \mathrm{r}$ Club, is represented in the Kriendler Collection. With a vigilant eye, a pleasing address, and an ample stock of the cups that cheer, Host Kriendler besieges the authors who enter his public house; and the result is a genuine and ever-growing history of our literary times. If only the proprietors of the Tabard, the Mermaid, and the Mitre had been as farsighted!

... I often wonder what the vintners buy

One half so precious as the stuff they sell? ...

Autographed first editions, naturally.

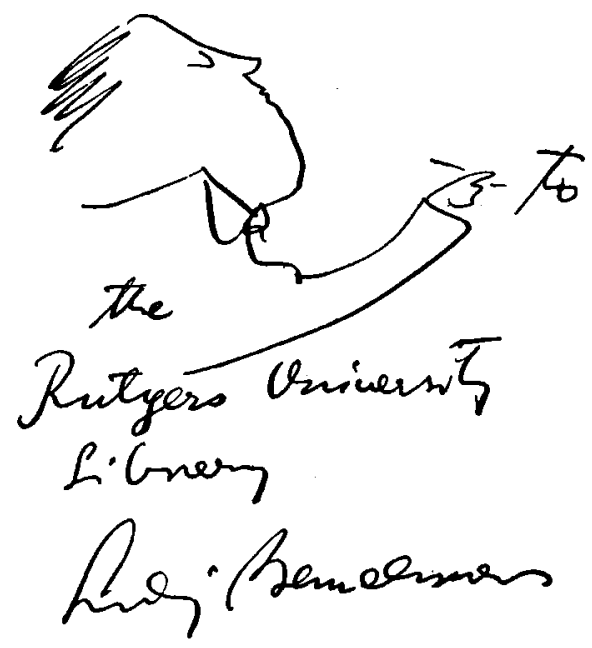

